$\mathbb{T}$ periodica polytechnica

Civil Engineering

$52 / 2(2008) 83+89$

doi: 10.3311/pp.ci.2008-2.04

web: http://www.pp.bme.hu/ci

(c) Periodica Polytechnica 2008

RESEARCH ARTICLE

\section{Hydraulic failure probability of a dike} cross section

\author{
László Nagy
}

Received 2008-03-08, accepted 2008-10-21

\begin{abstract}
This paper is a brief introduction on the determination of separate flood plain basins, the selection and determination of characteristic flood stages inducing typical economic impacts, and the principles of taking the safety factor or the probability of failure of the flood defences into consideration in flood risk mapping. The failure probability is the origin from the variability of the soil physical parameters and from the constantly changing water level.
\end{abstract}

\section{Keywords}

Probability of failure - conventional safety factor . flood risk . dike breach $\cdot$ soil characteristics $\cdot$ hydraulic failure

\section{László Nagy}

Geotechnical Department, BME, Múegyetem rkp. 3. Budapest, H-1521, Hungary

\section{Introduction}

Flood risk mapping is a cartographical representation of flood and flood damage characteristics of different probability. The maps are basic tools in flood prone areas for land use planning, for priority setting in the field of investments for the establishment or improvement of flood security, and they are also essential for insurance planning and for increasing the public awareness of risk [14, 17, 18, 20].

The important characteristics of floods influencing possible damages are the expected water level (or the expected depth of flooding), the frequency or return period of different water levels, flow velocity conditions, and flood duration. All of these characteristics can be represented in a flood risk map.

Flood risk maps are usually compiled for unprotected floodplains of river or creek valleys. In such cases the surface of the water flowing in the river bed can be computed as a variable unsteady flow in an open channel. Different water surfaces corresponding to discharges of different probability are determined, and the horizontal projection of the respective water levels to the terrain indicate the limits of flood of different probability. Characteristic depths of flooding are easy to derive from detailed topographic maps or digital terrain models. Such flood risk maps are usually used for land zoning or for the planning of structural flood alleviation schemes.

In Hungary, where $97 \%$ of the flood plains are already protected, we believe that the risk of damages can also be related to the stability or safety of the flood defence structures, dikes, and confinement dikes. The length of the Hungarian flood dikes is more than $4200 \mathrm{~km}$, so the flood risk is primarily a factor of the stability of the dikes.

\section{The inconsistency of soil characteristics}

The data or research findings that support the calculation of the degree of safety from the parameter of shear strength or the coefficient of permeability are normally scarce. It is common practice to calculate the central factor of safety from the average of research findings. A designer whose calculation takes into account the smallest of the available measurement results against the most unfavourable combination of loads exercises 
utmost caution. This calculation yields lower resistance values than the degree of safety calculated from averages. If a system still complied with the required degree of safety, the designed structure must have been uneconomically large. That has led on to a paradoxical situation: as spending on exploration grew, more and more studies were performed and the likelihood of receiving poorer and poorer resistance values kept increasing along with the safety of designing, which in turn kept driving the cost of construction higher.

Several researchers have studied soil characteristics as statistical values, such as the distribution and variability factor of soil features (Table 1). However, a review of the literature failed to identify data concerning studies on the coefficient of permeability and the type of distribution.

As a material used for supporting loads and for construction, soil is a substance that exhibits utmost variation in homogeneity. While a ten percent coefficient of variation $\left(\mathrm{C}_{v}=10 \%\right)$ represents poor quality for concrete, the value of $\mathrm{C}_{v}=0.4$ should be viewed as satisfactory with some soil characteristics (see Fig. 1).

Fig. 2 shows the results of 54 studies concerning the angle of internal friction and 91 studies of shear strength of the explored sandy and rich clay soils in the flood area of Köröszug. The results clearly demonstrate the relatively low coefficient of variation for sand.

\section{Safety of flood dikes}

The floods after 1945 have caused 140 embankment failures, of which 83 (58\%) were due to overtopping (52 during the 1956 icejam flood on the Danube), 23 (16\%) to hydraulic soil failure, $10(7 \%)$ to saturation and $2(1,5 \%)$ to leakage along structures, other identified $11(7,5 \%)$, while no cause could be identified positively in the case of $14(10 \%)$ [15, 16, 18, 19]. In the protected flood plain basins the occurrence of the various loss types can be related to the flood stages affecting the stability or safety of the flood defences. The total obtained is 143 instead of 140 due to the fact that in three cases different mechanisms of failure were named, which could not be judged as to their correctness. Evidently, the completeness of the list cannot be guaranteed.

Improvements over the past 150 years involved but rarely any change in the original trace of the embankments. Explorations of the subsoil and soil mechanical tests have been introduced as late as 3540 years ago, which recently revealed that the original trace passes over areas with adverse soil conditions, where the soil profile contains:

- the meander crossings with its different soil layers,

- layers of organic soil or peat,

- dispersive soils,

- loose, poorly graded fine sands in the vicinity of the surface, etc.

The programme for the investigation of $4200 \mathrm{~km}$ flood dikes was compiled in the 1980s for exploring the subsoil of flood embankments and for identifying the potential sections of piping failure. The basic considerations underlying the method are as follows:

- the subsoil under long embankments of moderate height must be investigated,

- the soil profile must be explored continuously (virtually by metres), and

- the subsoil consists generally of a cohesive cover over layers becoming increasingly coarser with depth.

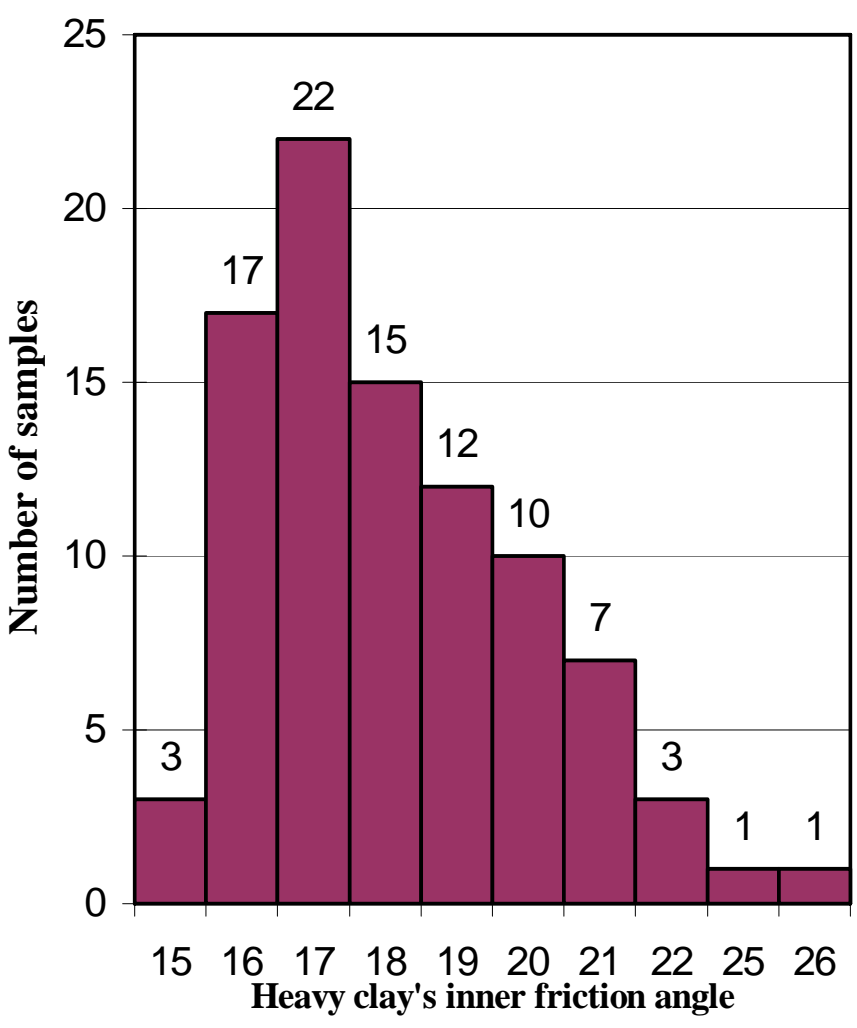

Fig. 2. The angle of internal friction of soils explored in the flood area of Köröszug

In order to carry out the investigation on the stability of the dikes, the study must be divided into characteristic sections, within which the following should be presumed more or less constant:

- the high of the crest,

- the stratification of foundation soil and the quality of the layers,

- material of the existing dike as well as that of the reinforcement or new defences,

- typical cross-section of the existing dikes, and

- phenomena observed along the dikes during floods.

The section conforming to the characteristics of the foundation soil has a special importance and needs special care. In the course of the investigation the safety of the embankments 
Tab. 1. The distribution and variability factor of soil features

\begin{tabular}{|c|c|c|c|c|}
\hline \multirow{2}{*}{ Soil properties } & \multicolumn{3}{|c|}{ Distribution } & \multirow{2}{*}{ Coefficient of variation } \\
\hline & Normal & Lognormal & Other & \\
\hline \multirow{2}{*}{ Water content } & $\begin{array}{l}66 \% \text { Corotis } 4 \\
\text { Davidson } 5\end{array}$ & $33 \%$ Corotis 4 & $\begin{array}{l}\text { Pearson IV or VII } \\
\text { Rétháti 23. }\end{array}$ & $\begin{array}{l}0,15-0,19 \text { Rétháti } 23 \\
0,02-0,2 \text { Borus-Rév } 1\end{array}$ \\
\hline & $\begin{array}{l}\text { Holtan } 8] \\
\text { Morse } 13\end{array}$ & & & \\
\hline Wet density & $\begin{array}{l}\text { Brust } 3 \\
\text { Ike } 9 . \\
\text { Prince } \\
\text { Rourke } 21 .\end{array}$ & & & $\begin{array}{l}0,011-0,028 \text { Borus-Rév } 1 \\
0,03-0,05 \text { Evangelista } 6\end{array}$ \\
\hline Particle density & Shultze (1971) & & & \\
\hline Void ratio & $80 \%$ Shultze 24 & & & \\
\hline Saturation & & & Rétháti 23 . & \\
\hline Liquid limit & $\begin{array}{l}80 \% \text { Shultze } 24 \\
66 \% \text { Corotis } 4 \\
\text { Lumb } 11\end{array}$ & $33 \%$ Corotis 4 & Rétháti 23. & $0,11-0,38$ Rétháti 22 \\
\hline Plasticity limit & Lumb 11 & Corotis 4 & & 0,04-0,10 Borus-Rév 1 \\
\hline Plasticity index & Lumb 11 & & Rétháti 23 . & 0,26-0,54 Rétháti 23 \\
\hline Shear test & $\begin{array}{l}\text { Hooper } 9 \\
\text { Insley } 10 \\
\text { Wu } 27\end{array}$ & & & $\begin{array}{l}\text { 0,15-0,31 Morse } 13 \\
0,17 \text { Weber } 26 \\
0,05-0,14 \text { Schultze } 24\end{array}$ \\
\hline Friction angle & $50 \%$ Shultze 24 & & & 0,06-0,11 Harr 7 . \\
\hline Cohesion & Lumb 11 & & & $\begin{array}{ll}0,42 \text { Weber } 26 & \\
0,26-0,68 \text { Lumb } 12\end{array}$ \\
\hline
\end{tabular}

Fig. 1. Coefficient of variation of soil characteristics

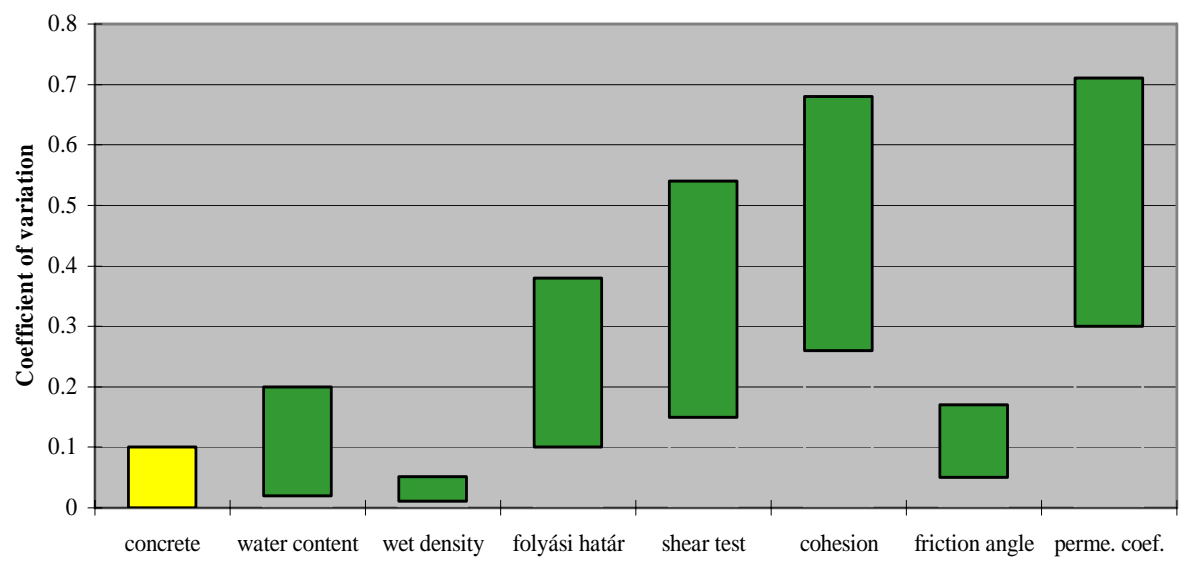

against piping failure is determined by successive approximations involving several disciplines, like geophysics, hydraulics, soil mechanics, and surveying. To determine the longitudinal profile of the long dikes and the individual sections, one of the best methods is the permanent horizontal geo-electric probing with a 1,0 meter electrode distance. The application of this method makes the exploration of continuous stratification possible. This method also reduces the cost of exploration, while the application of more expensive methods may be required less often and only for the identification of the layers at easily determinable points.

\section{Determination of the conventional safety factor}

Controlling the safety factor of the embankment divided into characteristic sections must be accomplished section by section, according to standard methods specified in appropriate guidelines and standards. The conventional safety factor is:

$$
n=R / Q
$$

where $R$ is the resistance (or strength), and $Q$ is the action effect (load). Using and transforming the equations determine the safety factor of the defences at actual water stages, and the flood levels corresponding to previously selected safety factors can be determined. 


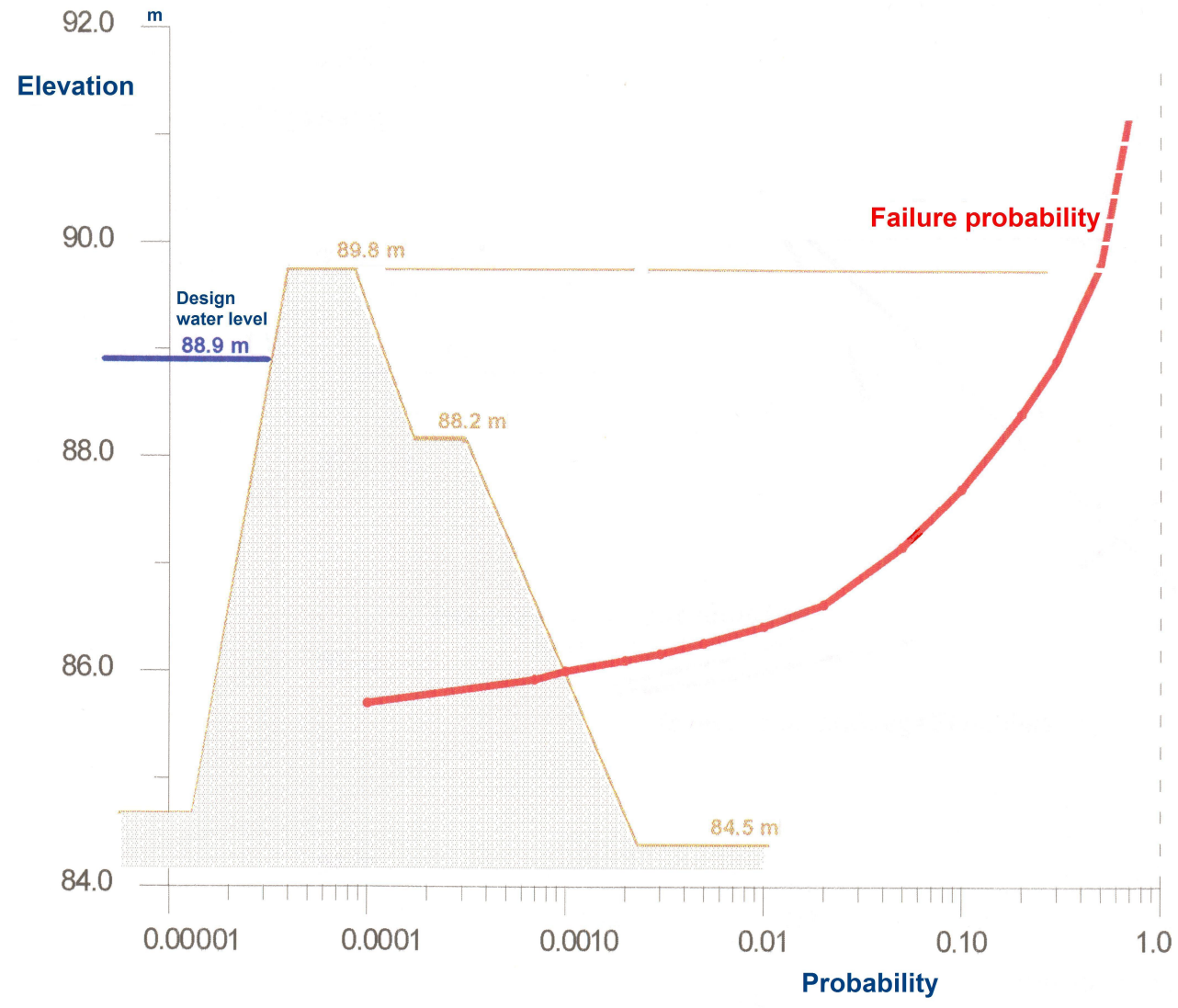

Fig. 3. Failure probability at different water stages

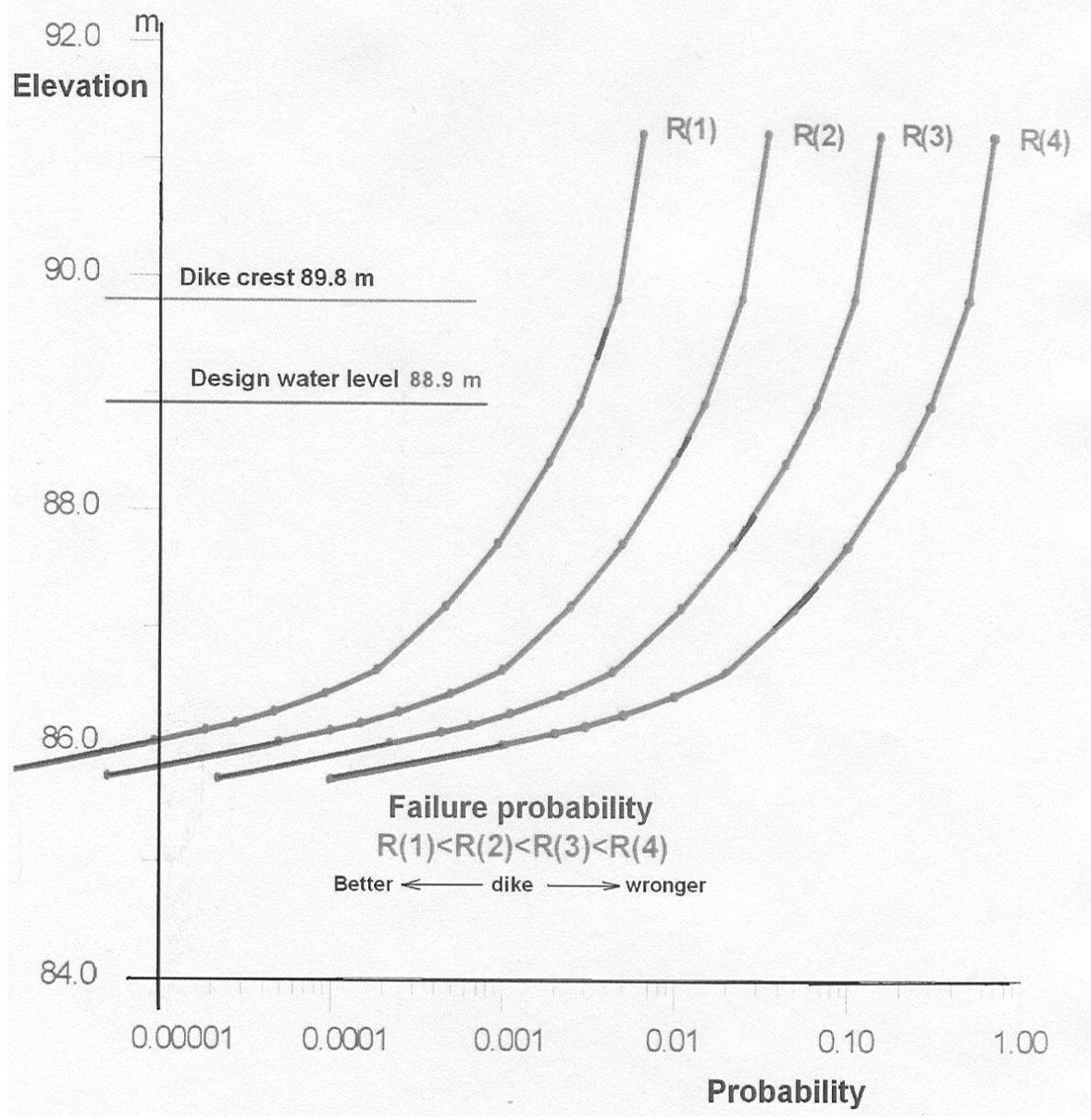

Fig. 4. Better and worse dike 


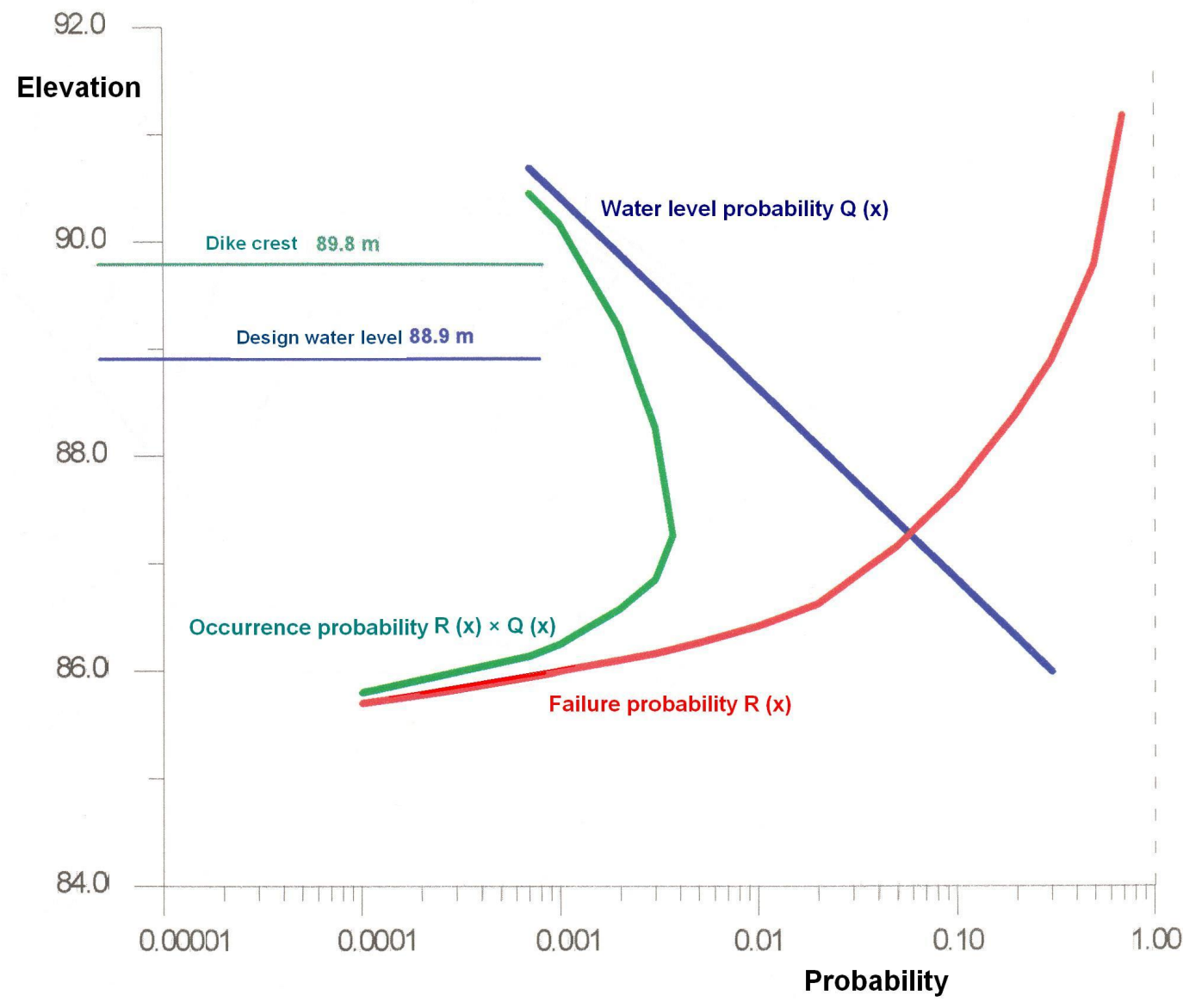

Fig. 5. The occurrence probability of a failure of a dike

So we have the opportunity of defining the flood hydrograph peaking at the level corresponding to the loading capacity of the defence structure. Since the most vulnerable cross sections of the defences are also known, the flood hydrographs representing the loading capacity are to be transformed to these possible breach points. The loading capacity of the defences can be determined by repeating the computations carried out earlier in order to define the extension of the floodplain of $1 \%$ probability of inundation, the extension of the flood plain section threatened by the stage corresponding to [25].

Advanced dimensioning methods consider both the impacts inducing $(Q)$ or hindering $(\mathrm{R})$ the breach to be independent and probabilistic variables. It is obvious that from the viewpoint of stability all the combinations of load and resistance are disadvantageous where $R<Q$, represented in the figure with the barred territory. The size of this territory is equal with the failure probability and therefore is appropriate for characterizing the magnitude of risk of the given section.

\section{The probability of failure at flood dikes}

In flood protection dikes both load and resistance develop along certain probabilities. Load is interpreted in terms of the probability of water levels. The variation of soils and soil characteristics prevents us from identifying in other than probabilis- tic terms what resistance to failure a flood protection dike will have under certain water level loads (probable water levels). When calculating the probability of failure, $Q(w)$ is used to represent the load probability function, as it is the function of water levels, whilst R (w) stands for the probability of resistance function, as it has been calculated from water levels.

The relation between load and resistance may be expressed by the safety margin (SM):

$$
S M=R(w)-Q(w)
$$

which is also a probabilistic variable. The failure probability expresses the probability of the opportunity of load exceeding resistance

$$
\left.p_{f}=P(Q>R)\right)
$$

or

$$
p_{f}=P(S M \leq 0)
$$

The failure probability can be determined either from the available soil physical data, applying probabilistic design methods for the whole calculation system or from the traditionally calculated safety factors using a semi-deterministic approach. For flood dikes the value of failure probability generally must be:

$$
p_{f}<0,01,
$$


Fig. 6. The hydraulic failure probability of an old and a developed dike

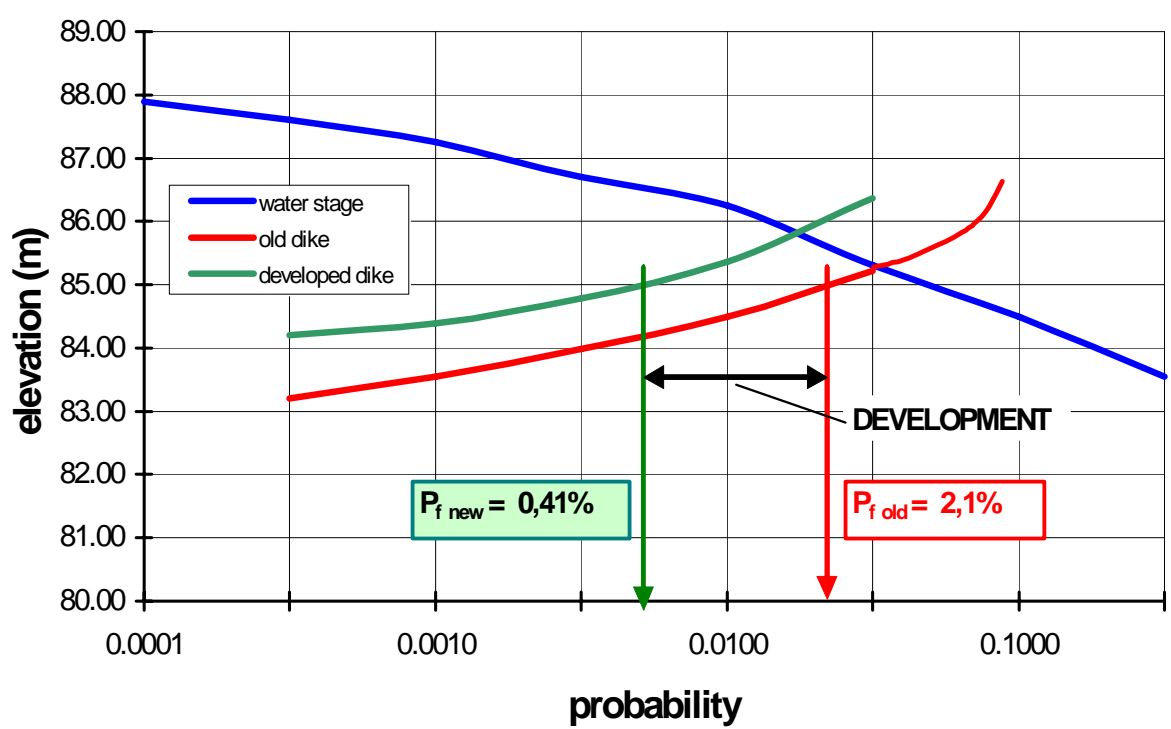

which means that among all possible combinations of load and resistance values only $1 \%$ would lead to breach. In other words, in $1 \%$ of possible cases will be $Q(w)>R(w)$.

I have prepared a detailed calculation to evaluate the safety of the protected flood areas along the Upper Tisza and the Sajó rivers. Based on the calculations and the dike failures of the past 35 years, it is recommended to provide the

$$
p_{f}<10^{-3}
$$

probability of failure of a cross section. At the present stage of the research, it can be identified as a boundary value for the probability of inundation (the probability of failure of a flood control dike multiplied by the probability of a flood event)

$$
p_{f}<10^{-5} \text {. }
$$

The calculations suggest that these values may also be applied in safety mapping. At present, there is no requirement in Hungary that specifies an acceptable value for the probability of failure.

It would only be proper to ask why would we use failure probability instead of the safety factor that we became accustomed to in practice? The answer is:

- we can characterize the system of defence structures,

- we can obtain the reliability of our results (uncertainties can be handled), and

- evaluation of risk is possible.

The hydraulic failure probability of a dike with conventional geotechnical methods can be caluclated for a given water stage. Repeating the calculation for more water stages gives the failure probability as a function of the height. Fig. 3 represents the results of the calculated values of the failure probability in the possible range of water stages, in addition to the probability of occurrence of water stages in case of a given profile of a dike [17]. Different failure probabilities are depicted on Fig. 4 depending on the water level. Since the failure probability and the occurrence of water stages are independent, the probability of their joint occurrence can be calculated as the product of the multiplication of their probability, that is $R$ (water level) $\cdot Q$ (water level).

Naturally, we are only aware of the size of resistance $(R)$ and size of load $(Q)$ functions to a certain level of probability as both are probability variables (Fig. 4).

Investigating the $R(w) \cdot Q(w)$ function, the occurrence probability of a failure of a dike profile can be characterised by the maximum value of $R$ (water level) $\cdot Q$ (water level) function. This consideration is interesting enough for further investigation.

The hydraulic failure probability of a dike at a certain water stage is shown in Fig. 6. After the proposed development the new dike failure probability is less then twenty $\%$ of the old one.

\section{Conclusions}

How safe is any given dike? The answer is provided by a probabilistic risk assessment, the benefits of which were described along with a standard for tolerable risk. It was stressed that in the absence of analytical techniques, the difficulty of assigning probabilities can be addressed through the use of experienced engineering judgement who is familiar with the dike and with all investigations and previous studies at their disposal. It was proposed that a risk could become a systematic and comprehensive framework for the application of engineering judgement.

Risk is the product of failure probability and consequences of the failure. The application of failure probability in the evaluation of existing and also in design of new flood defence structures gives us the possibility of adapting these problems to the risk standards. A standard for tolerable risk is needed in conjunction with a risk analysis to evaluate dam safety, its purpose being to permit decisions on dike safety remedial work to be based directly on risk in a consistent and quantifiable manner. 


\section{References}

1 Borus S, Rév E, Földmunkák tömörség-ellenôrzésének megbízhatósága, Magyar Építőipar (1968), no. 7.

2 _ Talajfizikai jellemzók meghatározásának megbízhatósága, Budapesti Mû́szaki Egyetem Továbbképző Intézete, Budapest, 1970. Manuscript.

3 Brust KJ, HM van Bavel, Stirk GB, Hydraulic propertics of clay loam soil and the field measurement of water uptake by roots, 1968, pp. $322-326$.

4 Corotis RB, Azzouz AS, Krizek RJ, Statistical Evaluation of Soil Index Properties and Constrained Modulus, 1975.

5 Davidson JML, Stone R, Nielsen DR, LaRue ME, Field Measurement and Use of Soil-Water Properties, Water Resources 5 (1969), no. 6, 1312-1321, DOI 10.1029/WR005i006p01312.

6 Evangelista A, Pellegrino A, Viggiani C, The Influence of the Variability of Coarse Grained Materials Properties on the Stability of Earth Dams, 1975.

7 Harr ME, Mechanics of Particulate Media - a Probabilistic Approach, McGraw-Hill, New York, 1977.

8 Holtan HN, England CB, Lawless GP, Schumaker GA, Moisture-tension Data for Selected Soils on Experimental Watersheds (Oct 1968), 609. U.S. Dep. of Agr., Agr. Res. Serv.

9 Hooper JA, Buttler FG, Some Numerical Results Concerning the Shear Strength of London Clay, Geotechnique 16 (1966), no. 4.

10 Insley AE, A Study of a Large Compacted Clay Embankment-fill Failure, Geotechnical Journal 2 (1965), 274.

11 Lumb P, Safety Factors and the Probability Distribution of Soil Strength, Canadian Geotechnical Journal 7 (1970), no. 3, 225.

12 , The Variability of Natural Soils, Canadian Geotechnical Journal 3 (1966), no. 2, 74.

13 Morse RK, The importance of proper soil units for statistical analysis, 1971.

14 Nagy L, The base of flood risk mapping, Hidrológiai Közlöny 80 (2000), no. 4, 251-258.

15 _ 200 Years Dike Failures in the Carpathian Basin, Proceedings of the $2^{\text {nd }}$ International Symposium on Flood Defence (ISFD'2002), Balkema Publishers, Beijing, 2002.
$16 \ldots$ Geotechnical Aspects of Dike Failures in the Carpathian Basin, Proceeding of the $13^{\text {th }}$ European Conference on Soil Mechanic and Geotechnical Engineering, Prag, 2003.

$17 \ldots$, Flood risk based on the failure probability of flood dikes, Budapest, 2004. PhD thesis.

$18 \ldots$, Dike breaches in the Carpathian Basin, Periodica Polytechnica Civil Eng. 50 (2006), no. 2, 115-124.

19 _ Estimating Dike Breach Length from Historical Data, Periodica Polytechnica Civil Eng. 50 (2006), no. 2, 125-139.

20 Nagy L, Tóth S, Danger, Zone and Risk mapping, Vízügyi Közlemények LXXXIII (2001), 288-308.

21 Prince AB, Rancy WA, Some Morphological, Physical and Chemical Properties of Selected Northeastern United States Soils. Agr. Bxp. Sta., Univ. of N.H. Durham, June 1961. Misc. Publ. 1.

22 Rétháti L, A talajminták szükséges számának meghatározása valószínüségelméleti alapon, Mélyépítéstudományi Szemle (1978), no. 10.

23 _ Valószinúségelméleti megoldások a geotechnikában, Akadémiai kiadó, 1984.

24 Schultze E, The General Significance of Statistics for the Civil Engineer, Proceedings of the 2nd Intern. Conf. on Application of Statistics and Probability in Soil and Structural Engineering, Vol. III, Aachen, 1975.

25 Tóth S, Flood Risk Mapping and Analysis with Special Regards to the Vulnerability of Protected Floodplain Basins, Proceedings of the NATO ASI on Defence from Floods and Floodplain Management, Kluwer Academic Publishers, Budapest, 1995.

26 Weber E, Gehrisch M, Ein Beitrag zur Berechnung von Versagenswahrscheinlichkeiten für homogene Lockergesteinsböschungen, Proceedings of the 6th Danube-European Conf. on Soil Mechanics and Foundation Engineering Section 3, Varna, 1980.

27 Wu TH, Kraft LM, The Probability of Foundation Safety, Journal of the Soil Mechanics and Foundations Division, ASCE 93 (Sept. 1967), no. SM5. 